\title{
Two philosophers in search of a contradiction: a response to Singer and Kuhse
}

\author{
Thomas A Long University of Cincinnati
}

\section{Author's abstract}

Peter Singer and Helga Kuhse reject my claim that because their views on the morality of infanticide are metaphysically incommensurate with those of Paul Ramsey they cannot refute his position. According to them, I have failed to see that Ramsey contradicts himself. Once this is seen, no further refutation is needed. I argue that there is no contradiction and offer further thoughts on the metaphysically incommensurate.

In an article about the morality of infanticide I contended that at times the debate over this issue is irresolvable because the disputants have 'incommensurable metaphysical views' (1). This thesis was developed by attending to the writings of Peter Singer and Helga Kuhse, on the one hand, and those of the late Paul Ramsey, on the other. My conclusion was that because of irreconcilable metaphysics neither side to the debate can refute the other; that is, there is no way that either Singer-Kuhse or Ramsey can show the other side to be wrong.

Recently, Singer and Kuhse claimed that I am 'mistaken' (2). They argue that when Ramsey's position is spelled out 'more fully' it will be seen that I have failed to detect a 'glaring contradiction' in his writings about the equal value of all life and the proper management of Tay-Sachs infants. When this contradiction is made perspicuous, as Singer and Kuhse think they have done, it will be seen that Ramsey refutes himself. Thus, while Singer and Kuhse concede that 'there are aspects of our position which draw upon metaphysical views different from those of Ramsey', they see no need to address this metaphysical difference. No, Ramsey is his own worst enemy. He is convicted out of his own mouth, but Singer and Kuhse show him mercy because when faced with consistency he chose 'humanity and compassion'. Well, I doubt it.

In discussing the fatally ill Tay-Sachs infant, Ramsey says both: (i) 'All our days and years are of equal worth whatever the consequences' and (ii) the

\section{Key words}

Infanticide.
Tay-Sachs infant should not have its 'days prolonged with tubes ... the ethics of only caring for the dying' holds for any patient 'who has entered upon the process of dying. No treatment is indicated when none exists that can do no more than prolong dying' (3).

However, Singer and Kuhse detect a contradiction between (i) and (ii). If all of our days and years are of equal worth whatever the consequence, 'then why are the days of life gained by treatments which prolong dying not also of equal worth?' Singer and Kuhse believe that when faced with 'the crunch' (the TaySachs infant) Ramsey abandons his 'all life is of equal value' stance. He opts instead for a 'quality of ... days' standard, precisely the position advocated by Singer and Kuhse. For this, Ramsey is to be praised as a compassionate person, but not as a rigorous thinker.

But is there a contradiction? For Ramsey, life is a ' gift' from God (3). This means that the irreversible ebbing away of this gift (dying) has a religious significance; 'illness unto death ... is a sign that God is calling his servant home ... To the eyes of faith ... God gives and God takes away' (3). 'All our days and years' are of equal value because they are divine gifts, but it does not follow from this, as Singer and Kuhse think it does, that prolonging the life of a Tay-Sachs infant would amount to nothing more than adding more days of equal value to a life. It would not amount to this at all. Ramsey says that when the infant 'has entered upon the process of dying', then 'only caring' attention is proper. This is because the attempt to prolong the infant's life would be an impious intrusion into a process that is essentially sacred; it would be to exhibit hubristic deafness to God's call.

If my interpretation of Ramsey is correct, then he does not decide the Tay-Sachs case on 'quality of life' grounds. However, it may be thought that I have purchased consistency for Ramsey at too high a price. For on my view, he rejects treatment for a dying TaySachs infant on religious grounds, and not out of a concern for 'humanity and compassion'. I'll close with some thoughts about this.

To say of someone's position that it lacks 'humanity and compassion' is to characterise it, not to refute it. Furthermore, when Singer and Kuhse use this expression to praise Ramsey they beg a metaphysical question. That is, they are assuming that human 
suffering should be given a secular utilitarian interpretation. On this view, human suffering has no supernatural (non-secular) meaning. Whatever meaning it does have must be given to it by taking human, earthly happiness as the exclusive goal (utilitarian). At a minimum, those policies, institutions, etc that seek the reduction of suffering are the worthiest. Therefore, compassion and humanity consist in favouring those policies, etc.

The preceding is what I would call a metaphysical sensibility. Its acceptance or rejection is as much (if not more) a matter of how people feel about themselves and the world as it is about philosophers' arguments. Sensibilities emerge from and express varying degrees of thought, hope and desire.

Consider a quite different metaphysical sensibility, one eloquently expressed by Flannery O'Connor, a Roman Catholic authoress who wrote out of the American south. Her remarks were occasioned by reflection upon the cancer-caused death of a child.

'Ivan Karamazov cannot believe, as long as one child is in torment; Camus's hero cannot accept the divinity of Christ, because of the massacre of the innocents. In this popular pity, we mark our gain in sensibility, and our loss in vision. If other ages felt less, they saw more, even though they saw with the blind, prophetical, unsentimental eye of acceptance, which is to say, faith. In the absence of this faith now, we govern by tenderness. It is a tenderness which, long since cut off from the person of Christ, is wrapped in theory ... [the] charity [which] grows invisibly among us, entwining the living with the dead, is called by the Church the Communion of Saints. It is a communion created upon human imperfection, created from what we make of our grotesque state' (4).

O'Connor's is a radically different metaphysical sensibility from the secular utilitarian. She sees all human life as held 'fast in Christ'. Central to this interpretation of suffering is the passionate embrace of religious mystery.

If, as I believe, the fundamental question for medical ethics is: 'How should we interpret suffering?' then the two metaphysical sensibilities sketched above are the contenders simply because one is totally committed to a 'this-worldliness' while the other is 'other-worldly' (5). And should either one emerge the 'winner' this will be determined through a mysterious mix of everything that makes humans human - their thinking, hopes, desires, emotions and (unfortunately?) their capacity for self-deception.

Thomas A Long is an Associate Professor of Philosophy at the University of Cincinnati, Cincinnati, Ohio, USA.

\section{References}

(1) Long T A. Infanticide for handicapped infants: sometimes it's a metaphysical dispute. Fournal of medical ethics 1988; 14: 79-81.

(2) Singer P, Kuhse H. Resolving arguments about the sanctity of life: a response to Long. Foumal of medical ethics 1988; 14:198-199.

(3) Ramsey P. Ethics at the edges of life. New Haven: Yale University Press, 1978: 191-192, 146,147.

(4) O'Connor F. Mystery and manners. New York: Farrar, Straus and Cudahy, Inc, 1969: 227-228.

(5) The specifically Christian content of O'Connor's view is not essential to the point I am making. 